Islamic Heritage Architecture and Art II 199

\title{
ISRAELI SETTLEMENTS IN THE OLD CITY OF HEBRON
}

\author{
WAEL SHAHEEN \\ Department of Civil and Architectural Engineering, Palestine Polytechnic University, Palestine
}

\begin{abstract}
Since the occupation of the city of Hebron in 1967, the Israeli authorities started a series of closure in the Old City both in public and private properties in order to impose the reality of the occupation on the city and its citizens and push them into abandoning it and to obliterate its features. Ever since that date, the occupation authorities have begun implementing a settlement project that aimed to surround the city with settlements. They established a set of settlement outposts in the neighborhoods that contain historical buildings, provided full protection to settlers, and took all measurements in placing pressure on the Palestinians in order to push them to leave by issued military orders that prevent the restoration and habitation of many buildings. They also completely closed all streets, neighborhoods and buildings of the Old City, forced curfews for long periods of time, and turned the Old City into a military barrack by establishing many barriers, monitoring and inspection points, which resulted the deportation of dozens of families, in addition to eliminating the economic recovery after shutting down many shops. Several parts of the Old City became completely deserted because of the economic consequences of land confiscation policy and many other policies like the multiple shutdowns and restrictions placed on movement. The Old City of Hebron still remains in 2017 similar to a ghost town, most of its streets are deserted and most of its shops are closed by welding iron, unlike the energetic and crowded streets on the other side of the checkpoint in area HI, where the Palestinian commercial activity moved to. Since the Old City of Hebron is an ancient masterpiece that must be preserved, this preservation requires highlighting the architectural and urban structure of the Palestinian centers in order to revitalize and rehabilitate it. It also requires exposing the hidden actions of the Israeli occupation in Judaizing Palestinian areas and overcoming these practices that prevent the rehabilitation process from taking its place, and that is the aim of this research.

Keywords: occupation, settlement, historical centre buildings, placing, closure, demolition.
\end{abstract}

\section{INTRODUCTION}

The Palestinian government, in cooperation with the Hebron Rehabilitation Committee, seeks to preserve the Old City of Hebron as an Arab and Islamic city with a long-standing cultural heritage, therefore they subsidy the restoration operation and encourage some of the European agencies to finance the ongoing projects in the Old City. By doing that they aim to achieve the following objectives, these objectives are:

1) Protect the history, heritage, and memory of the city for future generations, and increase citizen's awareness of the importance of the region.

2) Emphasize the responsibility of the community in preserving this heritage and the historical environment of the old town.

3) Provide a secure urban social environment that achieves social welfare and continuity of the population.

4) Encourage citizens to be present in the Old City by providing security for houses, markets, and shops, and to change their mental image of fear from living, visiting or shopping from it (Fig. 1 and Fig. 2) [1].

5) Reduce the occupation's practices and policies within the Old City that hinder the process of living and maintaining.

6) Find solutions to the problems of the Old City and the religious, historical and archaeological places where most of them have become destroyed and abandoned, 
they reflect the heritage and historical identity and are of an architectural style that should be given attention [2].

7) Evacuate the city center from the settlers and work to return the original inhabitants to their homes and rehabilitate and develop the area and prevent the settlers from taking over their homes and shops [3].

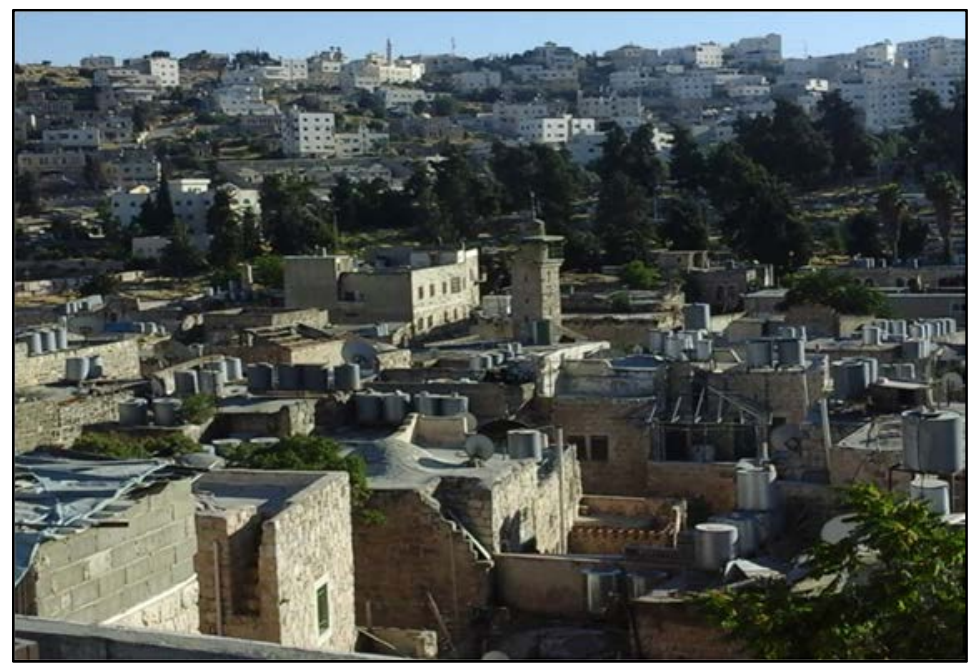

Figure 1: A view of the Old City from the west.

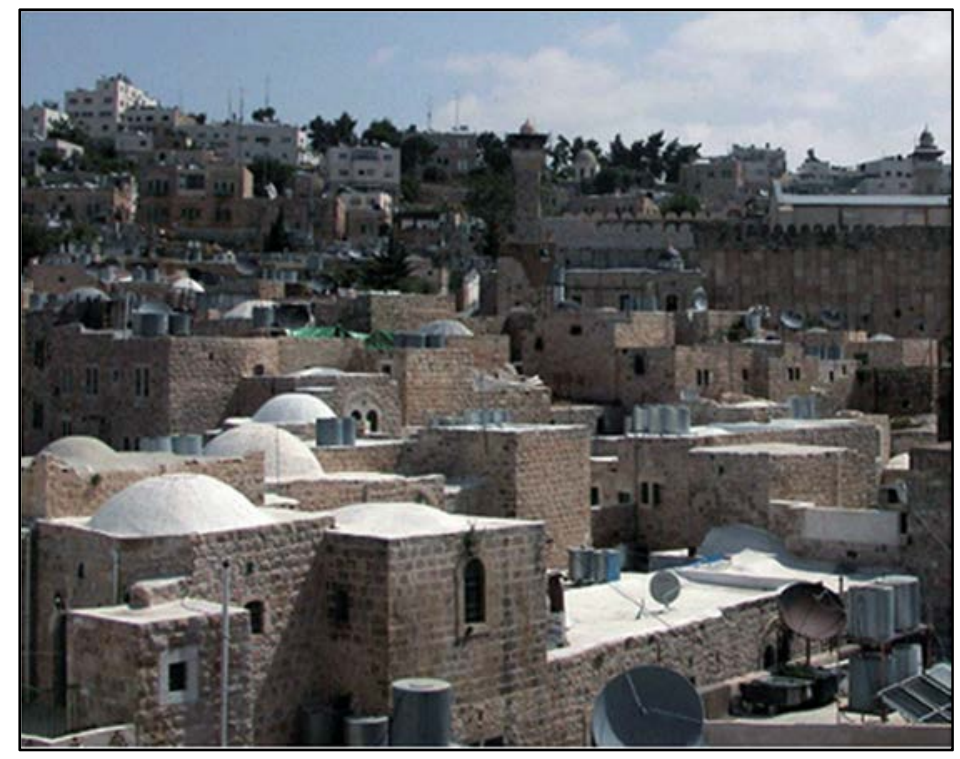

Figure 2: A view of the Old City from the east. 


\section{THE OLD CITY OF HEBRON: A HISTORICAL BACKGROUND}

Hebron is one of the oldest cities in the world and is situated $36 \mathrm{Km}$ south of the city of Jerusalem. It contains the Ibrahimi Mosque, which is considered one of the holiest religious places. The Old City of Hebron extended around this religious site to compose a group of homes which were built around fields separated by narrow alleyways, and its architectural engineering and the building of its neighborhoods goes back to the Mamluk Period (12501517) and the Ottoman period (1517-1917). The Old City contains many historic sites and markets, built of stone, most houses are characterized by dome-like ceilings, and the city is special with its narrow winding streets and covered alleyways, which connect to the Sacred Ibrahimi Mosque. The city presents an Islamic character in its ambience, where the mosque is surrounded by markets from all sides, that connect to specialized markets, followed by homes spread behind the commercial markets (Fig. 3).

The city has expanded since the beginning of the 20th century and has extended in all directions and in tandem with the road leading to Jerusalem and the road leading to the south. The urban fabric of the Old City was also distinguished by the interconnectedness of its houses and neighborhoods, which contained many architectural elements (Fig. 4). Their alleys and roads were characterized by arches that formed elements of containment and protection for their inhabitants from various factors, and their wide squares were used as a social space for the population [4].

The Old City today is home to a population of 6500 people, its area by 2015 was $1 \mathrm{~km}^{2}$ and has become characterized today by closed commercial stores and homes, empty streets, and the continuous and non-ending presence of the occupation's army and settlers. In addition, due to its political and religious importance, it has become a target of the colonial movement, as such within the 80 s of the passing century, many illegal colonies were built inside the town, this was followed by many restrictions on the movement and entry of the Palestinians, and closing of roads, passageways, and streets. Aside from violation of basic human rights due to these policies, it is clear that it conflicts with the design of the Old City, and these restrictions imposed and violations by the colonial army stand in the way of fulfilling basic living needs and restrict freedom of movement. In addition, the colonies have been formed with complete disregard of heritage values, urban environment, and natural landscape, which has led to the corruption of heritage property and spaces and imposed restrictions on urban planning [4].

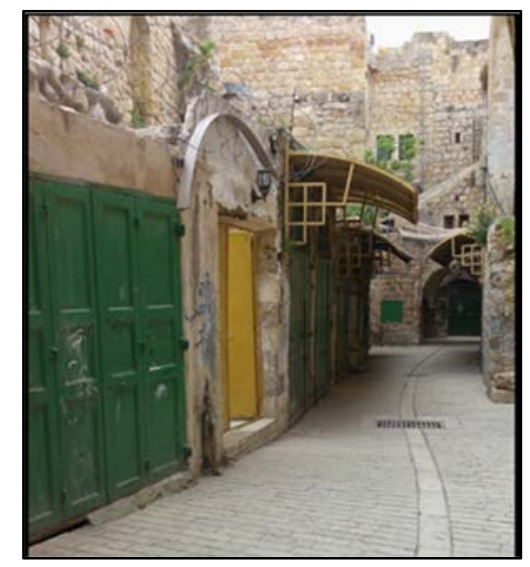

Figure 3: Roads and closed shops in the Old City. 


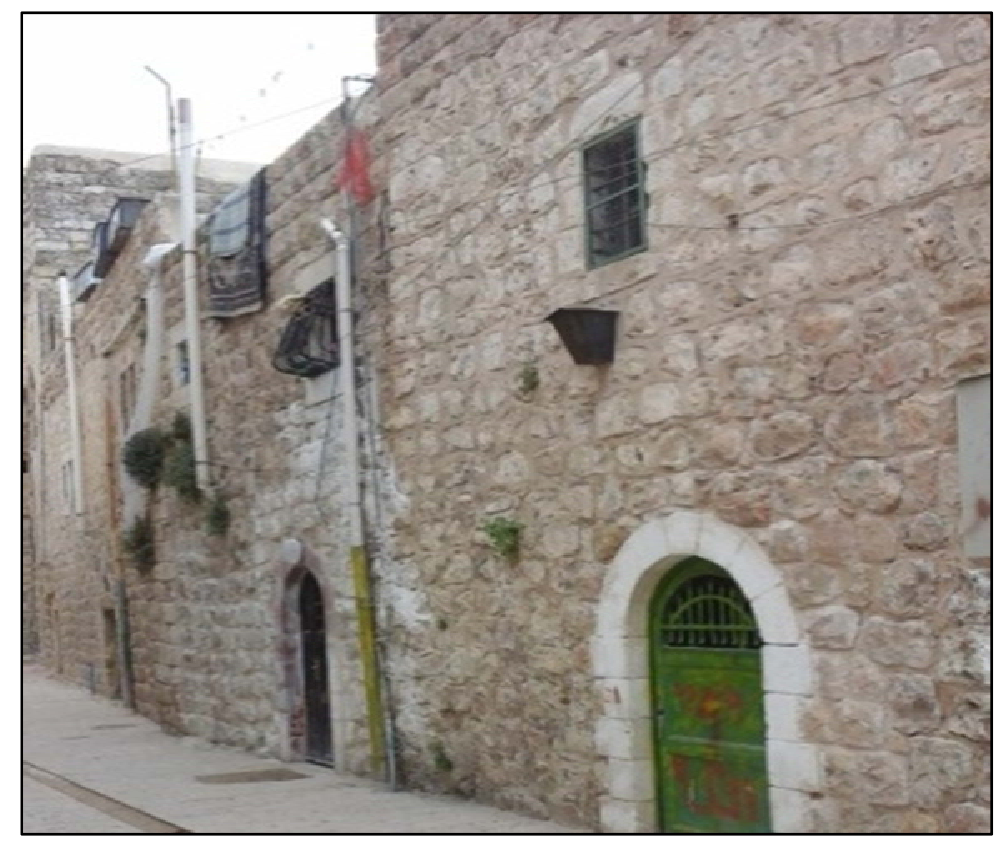

Figure 4: Houses of Bani Dar neighborhood.

\section{THE COLONIES AND SETTLEMENT OUTPOSTS IN THE HEART OF THE CITY}

Settlement outposts are colonies created by the occupation of settlers of the homes and lands owned by the Palestinians and are usually situated nearby existing settlements as a strategy to expand these settlements (Fig. 5). The Old City is subjected to constant violations by extremist Jewish settlers alongside the occupation forces since the 70 s of the passing century, which has led to the creation of six colonies in the Old City. These colonies are the Settlement of Beit Hadassah (Al Dabouya) (Fig. 6), which is a building in the heart of the city that used to be a school in the era of Jordanian rule. The Settlement of Avraham Avinu, a large residential building located near the old vegetable market in the center of the city (Fig. 7). The Settlement of Osama Ibn Munqez, which transferred to Beit Romano School by Israeli settlers. The Settlement of Tel Armida, which looks like a fortress surrounded by iron gates and watchtowers, this area is believed to be the site on which Hebron was built. The Settlement Commercial Center beside the Ibrahimi Mosque (Gautic). Beit Al-Rajabi settlement, in 2014, an official colony was established in the house of Al-Ragabi family, which Israel recognized and supported [5].

The population of the settlers in the Old City varies between 400-800 settlers, who live under the protection of a large force of the occupation army inside and around the city, in which the streets and roads around the settlements have been closed to the Palestinian and have been left open for the settlers and occupation forces. The street standing out the most from among these is Al-Shuhada'a Street, which separates the north of the city from its south, and its closure has forced residents in the Old City to spend a longer time to get around and reach the city (Fig. 8) [6]. 


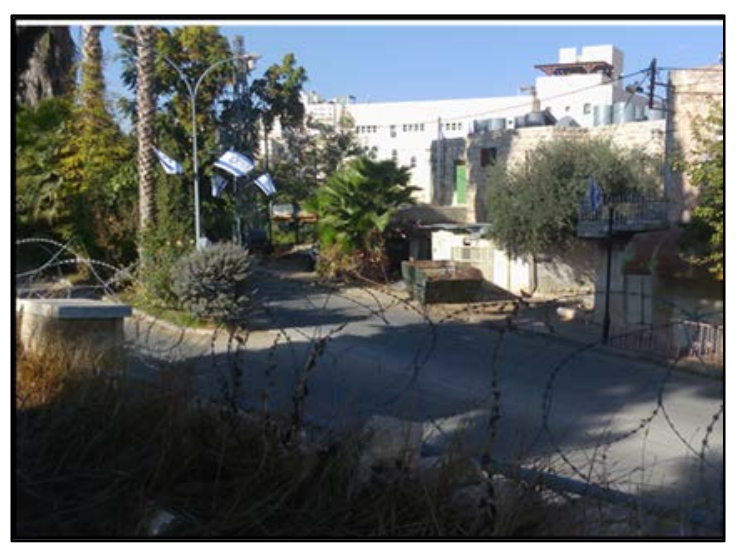

Figure 5: The Israeli closed.

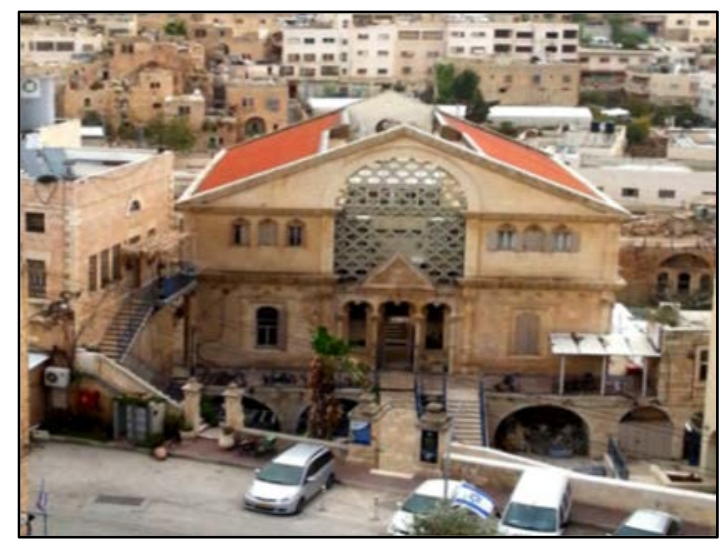

Figure 6: Al Dabouya settlement.

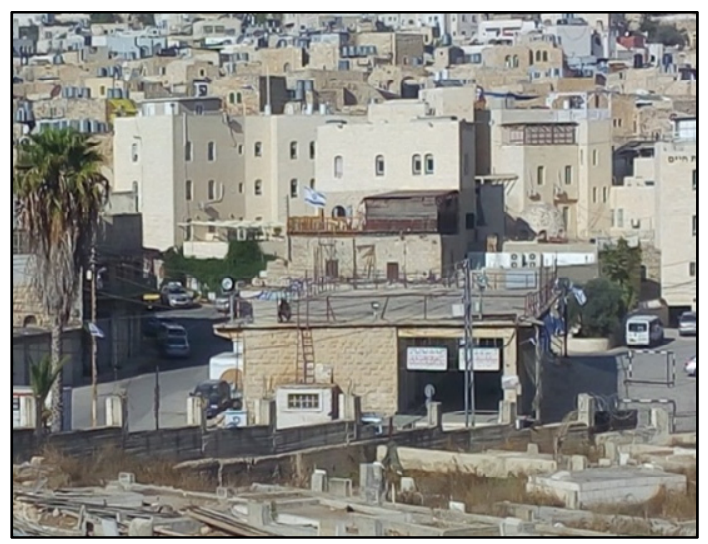

Figure 7: The Avraham Avinu settlement. 


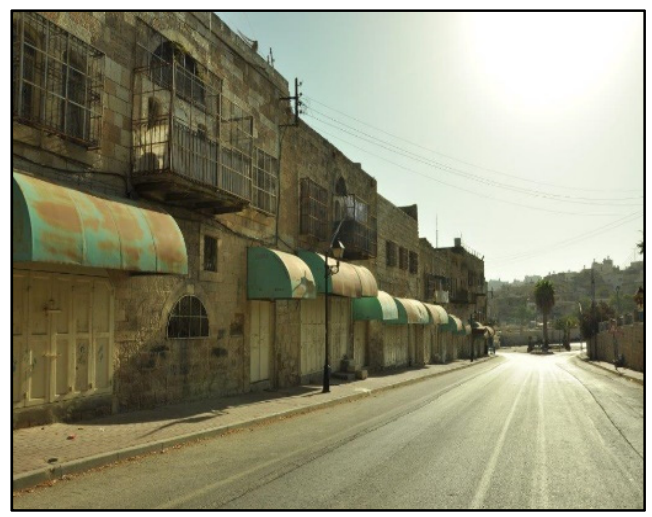

Figure 8: Closed shops in Shuhada'a street.

The establishment of settlements in the Old city has deprived the Palestinians from their right of residence, and the efforts of the Israeli occupation forces to limit the Palestinian presence in the city takes various forms, such as the confiscation of residential property and restrictions on access to certain places. The army identified a range of land in the center of the city where the movement of Palestinian vehicles and pedestrians is prevented, in addition to the many examples of methods of abuse, physical violence, shooting, robberies, denial of family reunification and the presence of Israeli soldiers at every corner to protect the settlers and harass the Arab population. These policies affect mostly the Palestinians living in Tel Armida neighborhood and al Shuhada'a Street. In addition to the Israeli unjust action against the citizens of the city, where the occupation completely closed the archway of Khuzq AlFar gate With a metal door, which made it a dam blocking the flow of rainwater through this archway to its natural course through the Hebron Valley. As a result, the winter rainfall in the Old City increased to about $150 \mathrm{~cm}$, which led to the leakage of water into shops and low-lying houses, causing numerous collapses, environmental pollution, and saturating the foundations of buildings with mineral salts and contaminants [6].

\section{DISCRIMINATION IN PLANNING AND CONSTRUCTION}

The occupation army maintains full control of the planning and construction process by establishing and implementing comprehensive strategies for the area, the division of the city into two areas (H1 and $\mathrm{H} 2$ ) (Fig. 9) represents an organizational planning decision that affects the residents of the area and gives Israel full control over urban planning in area $\mathrm{H} 2$ and gives it authority to determine the current and future use of the area. The absence of any Palestinian planning committees or any form of participation of Palestinians residing in the Old City leads to inequality in the use of private and public space and participation in the development and decision-making of the organization and planning of their neighborhoods and residences. Israel dominates over organization and planning in excavations and archeological finds, as in Tel-Armeda, which began in 2014, where Palestinians fear that these excavations will lead to the expansion of the settlement established in Tel-Armeda. There are restrictions that do not allow the Palestinians to expand urban areas for the purposes of natural population growth, and allow Israeli Jews alone to reside in the colonies and surrounding areas through military confiscation of the roofs and floors of houses and the denial of the rehabilitation and construction of homes and the denial of the use of public space and public utilities. 


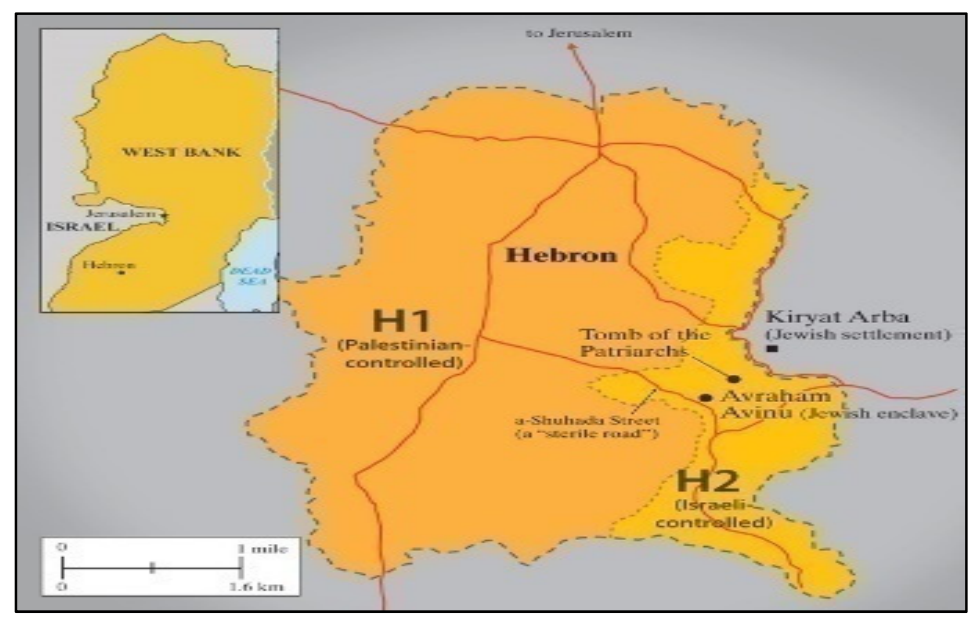

Figure 9: Map of the city of Hebron after the division.

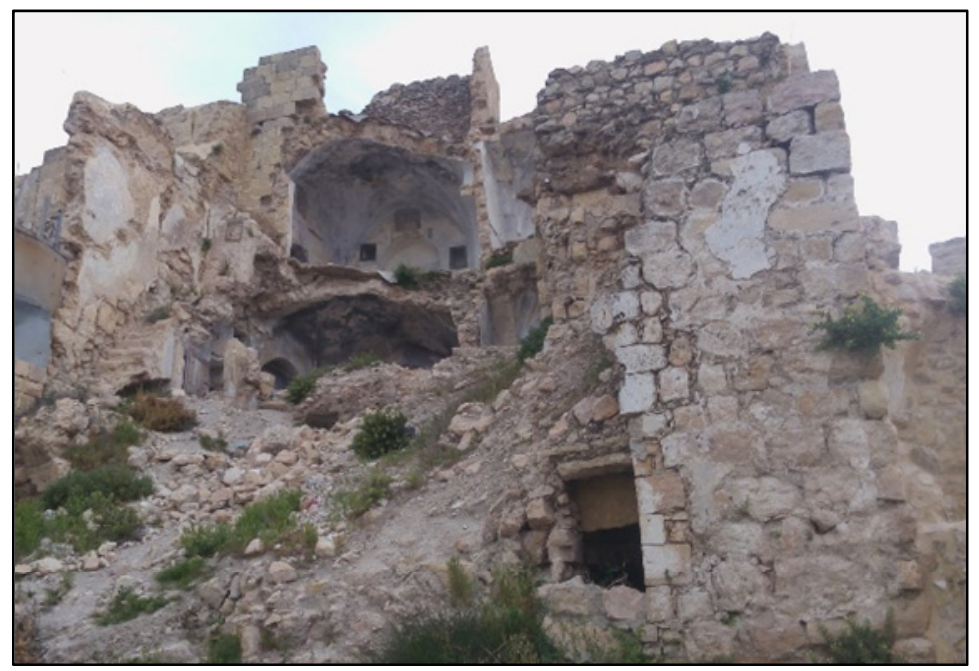

Figure 10: The destroyed in Old Town after the division of the city.

In addition, issuing military orders to open new settlement roads, such as the order that opened a settlement road linking the settlement located in Tel Armida to the middle of AlShuhada'a street, and the military order, which destroyed the historic buildings in the Old City of Hebron to create a settlement road linking the settlement of Kiryat Arba to the Ibrahimi mosque (Fig.10) [7].

\section{POLICIES OF FORCED DISPLACEMENT AND LAND CONFISCATION}

Palestinian residents living in the Old City of Hebron are subject to the same Israeli policies of forced displacement as Palestinians throughout Palestine, but some policies and special circumstances in the Old City have increased the harsh environment, the division of the area 
into two regions and the military rule of area H1, in addition to the topographical features of the Old City has made the people's daily life a struggle for survival. This coercive environment imposed by the Israeli policies is increasing the continuously forced displacement of Palestinians in the Old City; families have been forced to leave the area in the last few decades as a result of the perpetration of the crimes of colonization. In 2015, the Israeli army closed the Tel-Armeida neighborhood, declared it a closed military zone and imposed restrictions over the residents and their movement, which affected the houses and streets (Fig. 11 and Fig. 12). The closure of the front doors by the Israeli army forced the families to search for alternatives such as the use of backdoors or the roofs of neighboring buildings to enter and leave their homes or even turn windows overlooking streets into entrances, which made the lives of many original residents almost impossible [8].

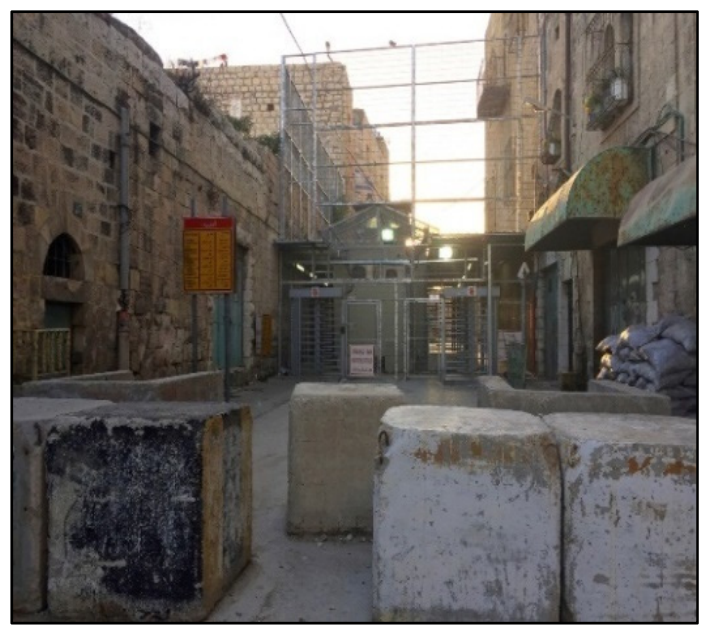

Figure 11: Shuhada'a street, North Ovest Old Town, checkpoint.

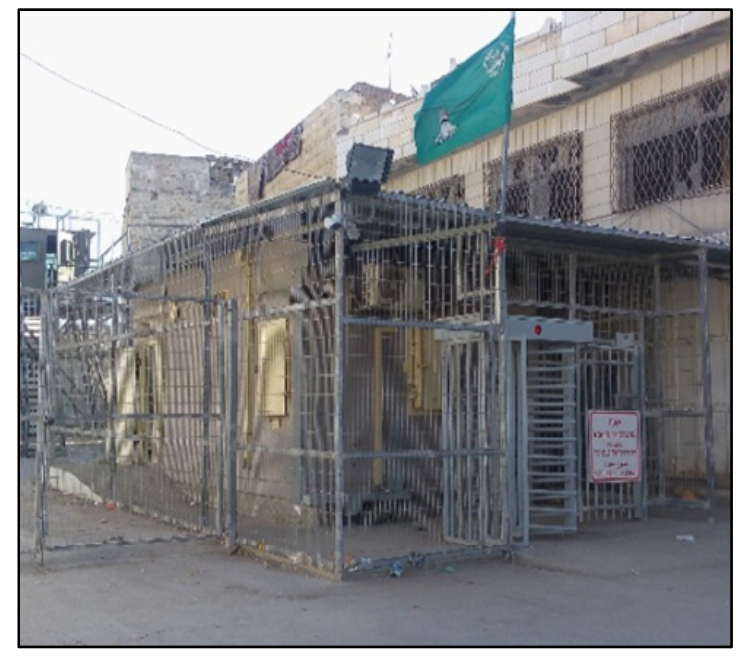

Figure 12: Al Shuhada'a street, South Old Town, checkpoint. 


\section{CONCLUSIONS AND RECOMMENDATIONS}

1) Develop legislations and laws on the protection of archaeological buildings, and monitor the damage suffered by the city and its impact on heritage.

2) Restore, maintain, rehabilitate and develop houses, shops, markets, public buildings, and streets while preserving the distinctive character of the urban fabric.

3) Preserve the historical, religious and cultural monuments in the Old City and continue its rehabilitation and maintenance efforts.

4) Improve living conditions, raise the level of the residential environment and provide an attractive environment to encourage people to live in the Old City.

5) Improve infrastructure and public utilities.

6) Improve the social environment by raising awareness among the population of the importance of preserving, for a better future for the individual and the family in terms of social, economic, health, cultural and educational.

7) Develop commercial markets and traditional crafts to improve the economic and tourism sector in the region.

8) Educational initiatives to raise awareness among the public about the value of archaeological heritage in understanding the past, and about the threats to this heritage and urban heritage.

9) Establish projects to support and revive human life in the heart of Hebron.

10) Pay attention to the educational sector in the Old City to enhance the steadfastness of the citizen and improve it to contribute to the preservation of national identity and the maintenance of national heritage.

11) Remove visual distortions and non-original additions to the components of the old town.

12) Prohibiting the establishment of any new facilities that are not necessary for the heritage site.

\section{REFERENCES}

[1] Researchers, International Conference for the Development of Historic Cities Centers and the Advancement of their Economic Reality, The Old Town, Hebron, Palestine, 2011.

[2] Studies of the Comprehensive Survey of the Old Town, Hebron Rehabilitation Committee and the Palestinian Fund for Employment and the Engineers Syndicate, 2014.

[3] Al-Madhoun, R., The Stages of Judaizing Hebron, Palestinian Affairs Magazine, Beirut Lebanon, 1998.

[4] Researchers, Old Hebron Historical City Charm and Architecture. Hebron Rehabilitation Committee, 2008.

[5] Al-Tafkaji, K., Israeli Settlements in the West Bank, Palestinian Geographical Center, Jerusalem, Palestine, 1994.

[6] Hebron Rehabilitation Committee, The Reality of Jewish Settlement within the Old City of Hebron, Hebron Palestine, 2003.

[7] Al-Sawahiri, K., Zionist Settlement in West Bank Cities (Hebron, Jerusalem, Nablus) Dar Al-Carmel for Publishing and Distribution-Amman-Jordan, 1984.

[8] Hebron Rehabilitation Committee, Comprehensive Plan for the Preservation of the Old City and its Revival. 